\title{
Det personlige informationssystem
}

\author{
Af Jette Hyldegård
}

\section{Introduktion}

Internettet og World Wide Web har muliggjort nye måder at publicere og få adgang til information på, som parallelt hermed - og den stigende informationsmængde - har skabt et tilsvarende øget behov for kvalificeret informationsfiltrering. Bibliotekarers og informationsspecialisters mantra "rette information til rette bruger til rette tid"' har med Internettet fået en ny betydning som i relation til systemdesign stiller nye krav samt indebærer nye formidlingsmæssige opgaver og udfordringer.

Som en relativ ny måde at skabe værdi på for slutbrugerne samt forbedre deres mulighed for at søge og finde relevant indhold, er mange institutioner, organisationer og serviceudbydere inden for de seneste år begyndt at tilbyde personaliseret adgang til deres portaler, websteder, digitale biblioteker og intranet.

Med personaliseret adgang menes ofte brugerens mulighed for at kunne skræddersy og tilpasse brugergrænsefladens indhold og layout til egne behov og præferencer. Tanken er at brugeren herigennem skal kunne opbygge sit eget helt personlige informa- tionsrum (miljø) med relevante informationskilder og tjenester samt interagere med brugergrænsefladen på en personlig og brugbar måde.

Ejerne af portalen, webstedet eller intranettet håber på den anden side at kunne forbedre betjeningen af brugeren, medarbejderen eller kunden ved at imødekomme dennes specifikke behov, tilbyde en brugbar, effektiv og tilfredsstillende interaktion med systemet og herved etablere en relation der vil opmuntre brugeren til at komme igen.

Mens personalisering er blevet en vigtig måde at facilitere brugerens informationssøgning og interaktion med et givent system på, viser erfaringer fra brugen af personalisering - især på internettet - at flere udbydere ikke har formået at skabe den tilstræbte personaliserede brugeroplevelse (f.eks.. Bonnet, 2002; Manber et al., 2000; Reamy, 2001). Der kan nævnes flere mulige grunde hertil. I følge Reamy (2001) kan det skyldes en manglende vidensstruktur i systemet der effektivt understøtter et match mellem brugernes behov på den ene side og relevant indhold på den anden. En anden forklaring kan være at personalisering med individfokus anvendes på områder, der pr. 
natur er socialt betingede. Han nævner som eksempel fejlslåene forsøg med personalisereret nyhedsformidling, hvor man har glemt at inddrage avislæseres adfærd - vi læser nemlig ikke kun målrettet mhp. udvalgte dele af en avis men browser og skimmer også for at holde os bredt orienteret og for at kunne deltage $\mathrm{i}$ den almindelige samfundsdebat. Af andre faktorer eller barrierer for succesfuld personalisering nævner Manber (2000) kvaliteten af selve standardgrænsefladen, dvs. om den i sig selv opfylder brugerens behov og dermed overflødiggør personalisering; manglende brugbarhed ved selve værktøjet til personalisering eller den valgte personaliseringstrategi (eller mangel på samme).

Blandt flere former for personalisering er 'Min-side'modellen i dag den mest udbredte tilgang. Den omfatter specifikt software og elementer til at opbygge et personligt informationsmiljø hvis indhold og layout alene er bestemt og kontrolleret af brugeren. En statisk model af brugeren bevares således i systemet indtil brugeren opdaterer eller ændrer sin opsætning. Andre tilgange baserer sig i højere grad på metadadata og bagvedliggende regler der automatisk matcher brugere og indhold - dog med mindre brugerkontrol til følge. Personalisering er imidlertid ikke et mål i sig selv men derimod et middel til bedre informationsformidling og brugerservice En hensigtsmæssig implementering af personalisering er således ikke kun et spørgsmål om valg af tilgang, men nok så afgørende også betinget af en forståelse for hvem brugeren er samt med hvilket formål personalisering skal implementeres i det givne system. Det forudsætter igen en god brugermodel (eller brugermodeller) der karakteriserer brugeren, f.eks. dennes behov, rolle, præferencer, opgaver, mål og søgeadfærd.

I denne artikel ses nærmere på begrebet personalisering samt forudsætninger og krav mhp. at skabe en personaliseret brugeroplevelse $\mathrm{i}$ et informationssystem. Afsnit to redegør for begrebet personalisering og gennemgår tre fremherskende tilgange til personalisering og deres karakteristika. Afsnit tre præsenterer som case et brugerstudie foretaget på Den Kongelige Veterinær og Landbo Højskole (KVL) i januar 2003. Afsnit fire behandler i forlængelse af de foregående afsnit krav og anbefalinger til personalisering mhp. systemdesign. Endelig indeholder femte og sidste afsnit artiklens konklusion.

\section{Hvad er personalisering?}

\subsection{Definition}

Personalisering afspejler en ny designfilosofi der foruden at fokusere på brugeren også er orienteret mod at levere en kontekstuel brugeroplevelse. I de seneste år har interessen for personalisering tiltaget som en måde at filtrere information og reducere 'information overload' på, understøtte selvbetjening og effektiv løsning af opgaver samt som en måde at facilitere vidensudveksling og -deling på (Blom \& Monk, 2003; Chia, 2002; Neuhold et al., 2003; Reamy, 2001). Personalisering kan også være socialt motiveret ud fra et ønske om at ville udtrykke sin identitet eller sit tilhørsforhold til en specifik gruppe eller et fællesskab (Blom \& Monk, 2003). Ifølge Blom \& Monk (2003, s. 195 ) kan personalisering defineres "as the process that changes the functionality, interface, information content, or distinctiveness of a system to increase its personal relevance to an individual". Bonnet (2001) supplerer denne definition ved at betone forudsætningen for personalisering "...[personalisation] involves a process of gathering user-information during interaction with the user which is then used to deliver appropriate content and services, tailor-made to the users needs...".

\subsection{Typologi}

Personalisering kan tage mange former, afhængig af målgruppens karakteristika og opgaver, den tilgængelige teknologi og den valgte tilgang. Fra et systemorienteret perspektiv er der især to former for personalisering der er fremherskende og ofte anvendt i portaler, websites og intranet. De kan betegnes profilbaseret personalisering og adfcerdsbaseret personalisering. Sidstnævnte omtales også under navne som 'collaborativ information filtering' og 'recommender systems' (Davenport, 2000, Neuhold et al., 2003). 
Profilbaseret personalisering er baseret på et match mellem brugerprofiler (brugerattributter) på den ene side og indholdsprofiler (indholdsattributter) på den anden side. Indhold refererer her til alt fra en e-mail til et program til et word-dokument til en nyhed til en person. Inden for denne tilgang kan man igen skelne mellem to typer: skrceddersyet personalisering (customization) og regelbaseret personalisering.

Skrceddersyet personalisering (ofte demonstreret ved 'Min-side'-tiltag) refererer til brugerens føromtalte mulighed for at kunne tilpasse brugergrænsefladen og vælge hvilke indholdskilder og tjenester systemet skal levere der modsvarer hans eller hendes behov, personlige interesser og præferencer. Kontrollen med brugergrænsefladens indhold og layout er således brugerdrevet. Brugeren udfylder først en brugerprofil med oplysninger om f.eks. navn, køn, interesseområder, dernæst en indholdsprofil der typisk foregår ved at brugeren 'klikker-af' fra en liste med forskellige kategorier af indhold. I en digital bibliotekssammenhæng kunne det som vist i Figur 1 være indhold som databaser, e-tidsskrifter, nyheder, links og referencematerialer. Brugergrænsefladens layout tilpasses ofte ved at ændre farve og stil eller ved at vælge hvilke portalelementer eller applikationer (også omtalt som 'portlets' eller 'slots') der skal indgå samt deres placering i brugergrænsefladen. Succesfuld brug af skræddersyet personalisering er betinget af antallet af relevante valgbare muligheder samt hvorvidt selektionskriterierne matcher brugerens behov. Endvidere kræver denne form for personalisering et højt engagement af brugeren for at kunne motivere denne til investere tid $i$ at tilpasse og løbende tilrette brugergrænsefladen. Motivationen er vigtig da der omvendt kan ligge en fare $i$ at systemet udelukkende afspejler behov og præferencer baseret på en statisk og mulig forældet model af brugeren.

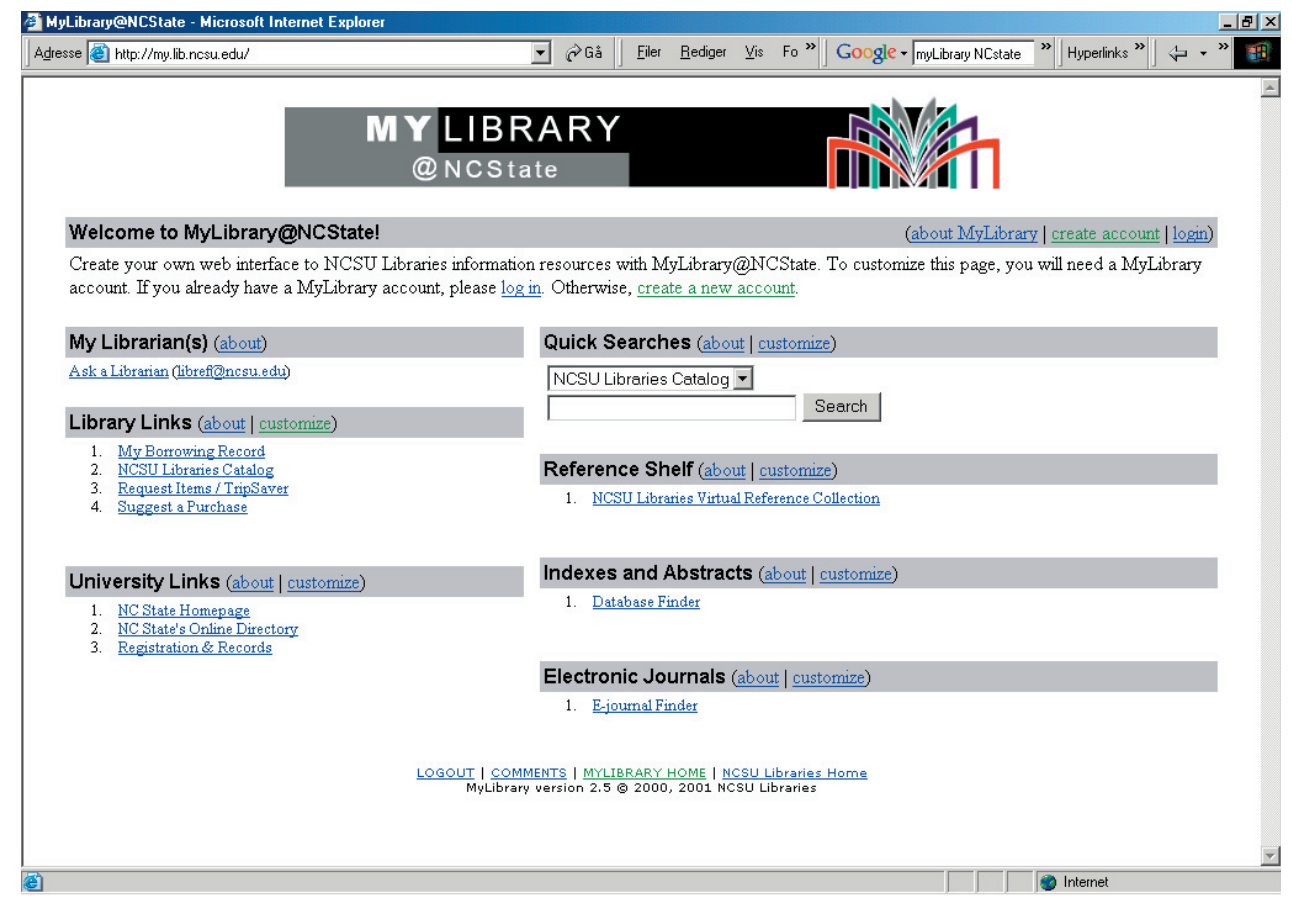

Figur 1: Eksempel på en skraddersyet webside. 'MyLibrary' fra North Carolina State University. 
Regelbaseret personalisering er personalisering opstået som følge af et systemkontrolleret match mellem bruger og indhold, baseret på et givent sæt regler. Det kan foregå meget simpelt som f.eks. når systemet via en cookie på brugerens pc husker brugerens indstillinger ved næste login. Det kan også foregå vha en mere avanceret brug af metadata og regler (Instone, 2000), som er den form der fokuseres på her.

Profilen - eller den enkelte beskrivelse - består af en række attributter (felter) og for hver attribut kan anføres en eller flere tilladte værdier (indhold af felter). Samtlige attributter og værdier bør beskrives og defineres i form af et vokabular som kan bestå af en taksonomi, etableret af den enkelte institution, organisation eller udbyder.

Brugerprofilen kan f.eks. indeholde oplysninger om navn, lokation, jobfunktion, rolle, kompetencer og niveauer samt interesser. Indholdsprofilen kan f.eks. indeholde oplysninger om typen (f.eks. bog, nyhed, email, person), ophav, titel, administrative data mhp. publicering eller rettighedstyring. Reglerne bygger på en given relevansopfattelse, idet de fortæller hvornår en brugerprofil (med en given beskrivelse) skal matches med et indhold (med en given beskrivelse). Figur 2 viser en konceptuel og logisk model af regelbaseret personalisering, herunder hvordan bruger- og indholdsprofil bestående af attributter og værdier forbindes via regler, der resulterer i et personaliseret output i brugergrænsefladen.

I praksis, når brugeren har udfyldt sin profil, benyttes den herefter proaktivt til at matche brugeren med relevant indhold i forhold til en given situation eller kontekst. Kontrollen over den personaliserede brugergrænseflade er således både bruger- og systemdrevet. Regelbaseret personalisering er foruden en målrettet filtrering af indhold også en vigtig måde at eksponere relevant indhold på for udbyderne - fremfor at vente på at brugeren tilfældigt falder over det $\mathrm{i}$ interaktionen med systemet. For at regelbaseret personalisering kan fungere optimalt er det imidlertid vigtigt at regler såvel som bruger- og indholdsattri- butter løbende og dynamisk tilpasses til og reflekterer brugerens aktuelle behov.

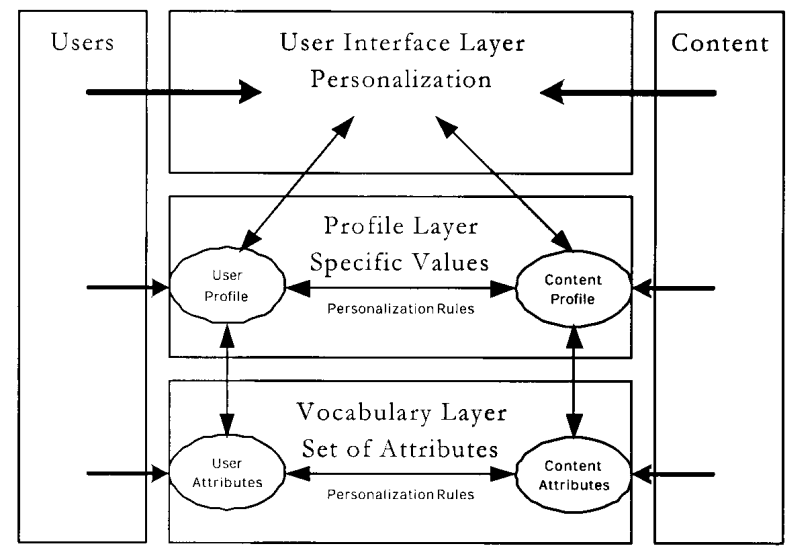

Figur 2:: Konceptual model af regelbaseret personalisering efter Keith Instone, 2000.

Adfoerdsbaseret personalisering refererer til personalisering baseret på en eller flere brugeres adfærd i et system. Det kan være køb af bøger som det benyttes hos internetboghandelen Amazon.com, brug af søgetermer og klik på specifikke links i en brugergrænseflade (Chia, 2002). Baseret på en simpel brugerprofil med fokus på personlig information og brugerpræferencer opbygger systemet dynamisk en model af brugeren eller af et specifikt fællesskab (community) baseret på den konkrete adfærd i systemet. Modellen bruges dernæst til automatisk at filtrere, anbefale eller matche brugere med relevante informationer og tjenester. Amazon anbefaler f.eks. information baseret på brugerens tidligere køb eller på baggrund af andre brugeres køb, der er emnemæssigt beslægtet med den konkrete brugers interesse. Det fremgår nederst på Figur 3, hvor den potentielle kunde her præsenteres for andres køb af bøger i et formodet slægtsskab med bogen Information architecture. 


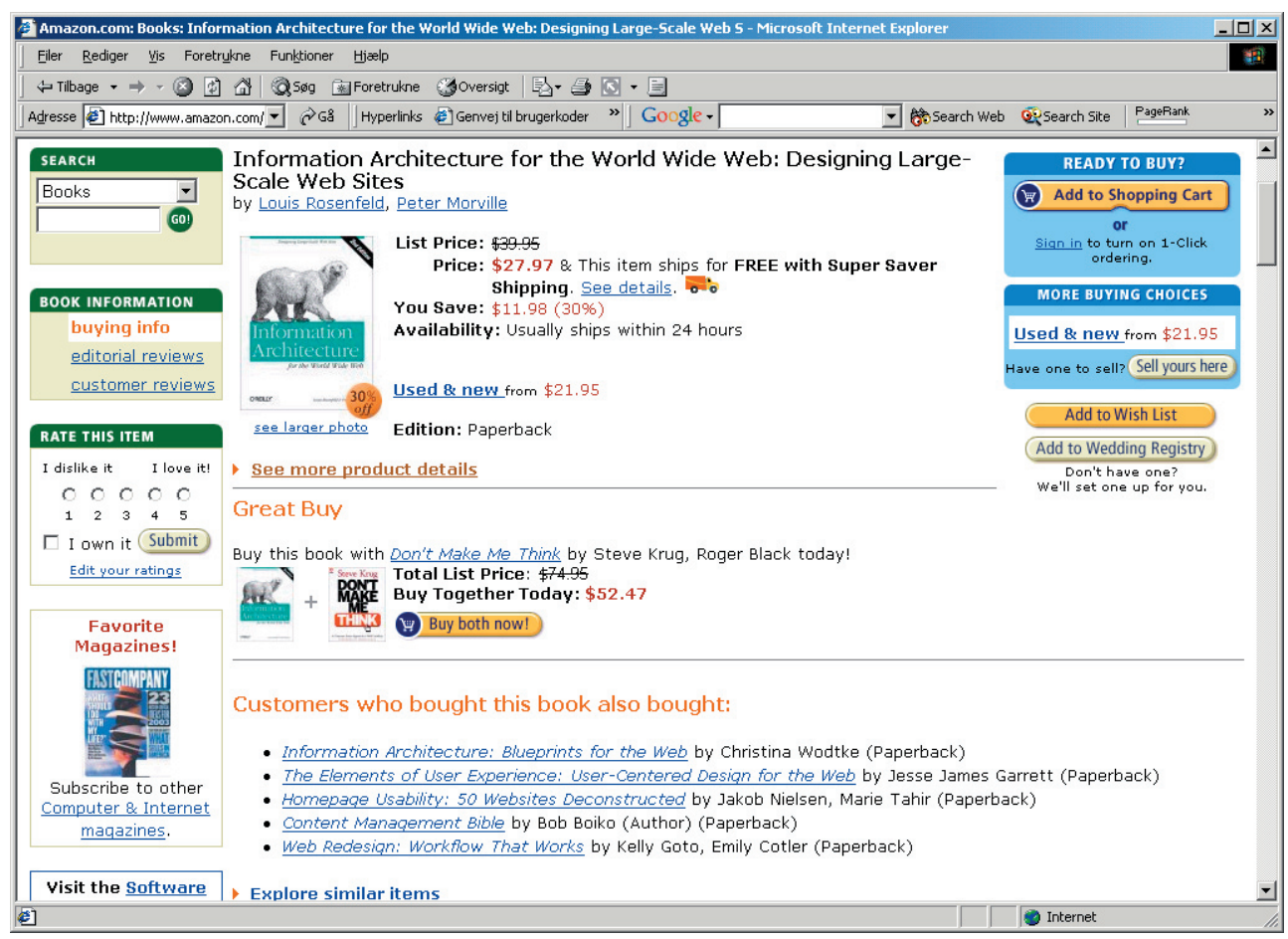

Figur 3: Eksempel på adfardsbaseret personalisering fra Amazon.com

Adfærdsbaseret personalisering er primært systemdrevet og efterlader kun brugeren med minimal kontrol over indholdet, hvis man ser bort fra at kvaliteten implicit er proportional med brugerens aktivitet i systemet.
De enkelte personaliseringstyper og deres karakteristika fremgår af Tabel 1. En personaliseringstype udelukker imidlertid ikke en anden i den konkrete systemløsning, men én type vil dog ofte være dominerende.

\begin{tabular}{|c|c|c|c|}
\hline Tilgang & $\begin{array}{l}\text { Skræddersyet } \\
\text { (Customization) }\end{array}$ & Regelbaseret & Adfærdsbaseret \\
\hline Input data & $\begin{array}{l}\text { Profil } \\
\text { (bruger \& indhold) }\end{array}$ & $\begin{array}{l}\text { Profil } \\
\text { (bruger \& indhold) }\end{array}$ & $\begin{array}{l}\text { Profil } \\
\text { (bruger \& andre brugere) }\end{array}$ \\
\hline Output data & $\begin{array}{l}\text { Layout, indhold, tje- } \\
\text { nester }\end{array}$ & $\begin{array}{l}\text { Eksponere kontekstaf- } \\
\text { hængig indhold og tje- } \\
\text { nester }\end{array}$ & $\begin{array}{l}\text { Eksponere og anbefale } \\
\text { relevant indhold }\end{array}$ \\
\hline Initiering & Bruger & Bruger/system & System \\
\hline Brugerkontrol & Нøj & Middel & Lav \\
\hline Brugermodel & Statisk & Statisk / dynamisk & Dynamisk \\
\hline Successkriterier & $\begin{array}{l}\text { Antal valgbare relevante } \\
\text { indholdselementer og } \\
\text { tjenester, selektions- } \\
\text { kriterier, opdatering af } \\
\text { profil }\end{array}$ & $\begin{array}{l}\text { Differentierede bruger- } \\
\text { og indholdsprofiler, } \\
\text { match-kriterier og op- } \\
\text { datering }\end{array}$ & $\begin{array}{l}\text { Kvaliteten af den ad- } \\
\text { færdsbaserede slutnings- } \\
\text { regel mhp. anbefaling af } \\
\text { relevant indhold }\end{array}$ \\
\hline
\end{tabular}

Tabel 1: Personaliseringstyper og deres karakteristika 


\subsection{Refleksion af 'mig'}

Personalisering er ikke en absolut størrelse, men snarere en refleksion i brugergrænsefladen der kan differentieres med det enkelte individs rolle, opgave eller kontekst (Hicks \& Tochtermann, 2001). En medarbejder i en virksomhed kan således både have behov for at se sig selv (i brugergrænsefladen) som medlem af en given organisation/kultur, som medlem af et projektteam eller et interessefællesskab samt som individ. Ligeledes er brugere af et elektronisk bibliotek ikke bare 'lånere' men også borgere i en bestemt kommune eller bydel, studerende, enlige osv. - i begge tilfælde oplysninger der med fordel kan indgå som grundlag for personalisering 2 . Ved indhentning af oplysninger om brugeren mhp. design (behov, opgaver, mål og præferencer) er det derfor vigtigt også at relatere disse til eventuelle roller eller funktioner brugeren måtte have.

Der gøres i disse år flere erfaringer med personaliserede løsninger, der bidrager til den praktiske håndtering og implemetering af disse. Men når det kommer til egentlige brugerevalueringer af personlige systemer eller personaliseringsfaciliteter er de svære at få øje på. I næste afsnit beskrives et brugerstudie foretaget på KVL i 2003 (Hyldegård \& Seiden, 2004). Studiet havde til formål at identificere forskeres krav og holdninger til personaliseret adgang til videnskabelige e-tidsskrifter og lignende forskningsrelevante tjenester.

\section{En case - et brugerstudie på KVL}

Inden for de seneste år har flere videnskabelige tidsskriftsforlag og informationstjenester også implementeret personaliseringsfaciliteter med mulighed for brugeren at skræddersy sit eget personlige informationsmiljø. Men har den form for personalisering relevans for brugeren i en forskningsmæssig sammenhæng samt hvilke faktorer eller succeskriterier vil i givet fald være afgørende for at relevansen af personalisering for denne målgruppe? For at finde et muligt svar herpå blev der udført et brugerstudie blandt en gruppe ph.d. studerende på KVL i januar 2003.

\subsection{Deltagere}

I studiet deltog 14 ph.d. studerende fra KVL. Alle deltagere var erfarne internetbrugere, men havde ingen tidligere erfaring med personalisering eller kendskab til de tjenester der blev benyttet i studiet. Helt i overensstemmelse med andre studier af forskeres informationsadfærd (e.g. Tenopir \& King, 2002) var videnskabelige tidsskrifter deres foretrukne informationskilde; og parallelt til en undersøgelse af RuschFeja \& Siebeky (1999) blev e-tidsskriftet foretrukket fremfor det trykte tidsskrift og benyttet af de fleste deltagere på en ugentlig eller månedlig basis.

\subsection{Test-cases}

I studiet indgik tre leverandører af personaliseret adgang til elektroniske tidsskrifter og tjenester: Science Direct (www.sciencedirect.com), Ingenta (www.ingenta.com) og Community of Science (CoS) (www.cos.com). Hver af dem har implementeret forskellige personaliseringsfaciliteter - overvejende baseret på 'Min-side'-modellen.

\subsection{Procedure}

En uge efter brugerne var rekrutteret modtog de en introduktion til selve undersøgelsen. Efter at have introduceret dem til hver af de tre tjenester blev de bedt om at udføre et sæt opgaver i hver dem med det formål at afprøve forskellige personaliseringsfaciliteter. Dernæst skulle de udfylde et spørgeskema. To uger efter at spørgeskemabesvarelserne var indleveret blev der afholdt et to-timers fokusgruppeinterview. Målet var således ikke at foretage et sammenlignende studie mellem de tre tjenester, men at 'tvinge' deltagerne igennem forskellige former for personalisering som grundlag for at kunne udfylde spørgeskemaet samt deltage i fokusgruppe-interviewet senere.

Spørgeskemaet spurgte indledningsvist til deltagernes alder, kendskab til Internettet samt tidligere erfaring med e-tidsskrifter og personalisering. For at få et indblik i deres informationsadfærd mht. valg af informationskilder blev de bedt om at indikere betydningen af en række kilder med et tal fra 1 (lav) til 5 (høj). Endvidere skulle de på en skala fra 1 (lav) 
til 5 (høj) angive hvordan de opfattede brugervenligheden, effektiviteten og relevansen af hver af de tre tjenesters personaliseringsfaciliteter. Formålet var her at undersøge disse faktorers evt. betydning for deltagernes accept af personalisering. Afslutningsvis blev de bedt om at indikere deres enighed i en række udsagn relateret til personalisering på en skala fra 1 (uenig) til 5 (meget enig).

Fokusgruppeinterviewet blev gennemført 14 dage efter at spørgeskemabesvarelserne var indleveret. I interviewet deltog ni af de 14 deltagere. Den ene forsker i studiet agerede moderator, mens den anden tog detaljerede noter undervejs i overensstemmelse med emneoverskrifterne $\mathrm{i}$ en fortrykt formular (svarede til de emner der blev behandlet $i$ interviewet). Det drejede sig f.eks. om betydningen af de foromtalte tre faktorer, deltagernes foretrukne personaliseringsfaciliteter i relation til deres søgeadfærd, eksempler på mindre relevante personaliseringsfaciliteter samt deltagernes holdninger til profil- og adfærdsbaseret personalisering. Interviewet blev optaget på bånd.

\subsection{Resultat}

På baggrund af analysen af data fra spørgeskemabesvarelserne og fokusgruppeinterviewet blev der identificeret nogle mulige succeskriterier (eller barrierer) for forskeres brug af personalisering. Selvom resultatet af studiet vedrører personaliseret adgang til videnskabelige e-tidsskrifter og tjenester vil det dog også med fordel kunne indgå i generelle overvejelser vedrørende design af personlige informationssystemer.

Resultatet af undersøgelsen er opsummeret i listen nedenfor og gennemgåes kort herefter.

- Personalisering skal optimere søgning og fremfinding af relevant (pertinent) indhold - set $\mathrm{i}$ forhold til traditionel søgning

- Brugervenlighed, relevans og effektivitet synes at være gensidig afhængige faktorer, der påvirker brugerens oplevelse af systemet

- Funktionalitet der understøtter søgning og levering af relevant indhold er kritisk
- Indhold og tjenester der er til rådighed via en profil skal matche brugerens behov og præferencer og stamme fra en leverandør eller tjeneste, man har tillid til

- Muligheden for at kunne tilpasse brugergrænsefladens layout vurderes ikke at være vigtigt

- Generelle kvalitetsindikatorer som f.eks. afsenderdata, datering og sidens layout er vigtige at tage i betragtning mhp. at optimere tillid og brug

- Vejledning samt indbyggede strategier der faciliterer informationssøgning, levering af relevant indhold og opbygning af informationskompetence vil også være et relevant personaliseringselement at implementere

Nedenstående citater fra fokusgruppeinterviewet giver et umiddelbart indtryk af deltagernes oplevelser og forventninger til personaliserede løsninger, overvejende baseret på brugen af de tre tjenester:

"Enormt fedt at man kan vælge eller fravælge noget, så det kan blive overskueligt næste gang man går ind...". "Når man vælger nogle ting fra, glemmer man de udeladte" og "For at en side er interessant skal den tilbyde noget som Google ikke tilbyder..."

I overensstemmelse med andre studier (f.eks. Tenopir et al. (2003) viste deltagerne sig at være meget målrettede når det gjaldt deres forskningsprojekter, hvilket betød at når de søgte information var det med et helt specifikt mål eller informationsbehov i tankerne. Derfor var det heller ikke overraskende tid der blev fremhævet som en meget væsentlig faktor ved evaluering af en given søgetjeneste. Det fremgik i forlængelse heraf at ideen om personalisering i høj grad var båret af en forventning om øget effektivitet set i forhold til traditionel søgning.

Brugervenlighed og relevans viste sig ligeledes at være vigtige faktorer, dvs. i tilfælde hvor man kendte en given tjeneste og vidste at indholdet var relevant var man dog i højere grad indstillet på at gå på kompromis med brugervenligheden. Alle tre faktorer syntes dog at være gensidig afhængige, idet de- 
res score overvejende fulgte samme mønster - en høj score i f.eks. brugervenlighed var som regel fulgt af en tilsvarende høj score på relevans og effektivitet.

Med tid og effektivitet som centrale motivationsfaktorer for personalisering var det især funktionalitetsaspektet der blev fokuseret på i diskussionen af krav til et personaliseret system. F.eks. blev 'search alerts' (søgeprofil der med et fast interval afsøger en given database for nye dokumenter) flere gange nævnt som en vigtig facilitet der kunne minimere besvær og tid i forbindelse med søgning. Dog fremhævede flere at 'search alerts' ikke kunne stå alene, men stadig skulle suppleres af manual søgning. Som begrundelse blev nævnt at man ikke kunne være sikker på at søgeprofilen var optimal eller at den afspejlede aktuelle behov, hvis man f.eks. glemte at opdatere den jævnligt.

Muligheden for at kunne tilrette layout, ændre farver og elementernes placering på siden blev af flere nævnt som mindre væsentligt, udtrykt på følgende måde af en af deltagerne: "hvis man har lyst til at spilde tiden kan man altid cendre på farverne".

Accepten af profilbaseret personalisering syntes i høj grad betinget af faktorer som 'tillid' og 'relevans', dvs. hvem afkræver oplysningerne om brugeren og hvorfor (med hvilket formål) samt hvorvidt det vil resultere i relevant indhold, hvis man udfylder profilen. Muligheden for at kunne vælge indhold og tjenester til og fra blev imidlertid anset for at være en meget nyttig måde at reducere informationsmængden på.

I forbindelse med adfærdsbaseret personalisering blev 'tillid' ligeledes nævnt som en kritisk faktor for accepten af den form for personalisering. De fleste af deltagerne syntes igen om ideen med filtreret og anbefalet information som en måde at reducere informationsmængden på, men det afhang igen helt af hvem der anbefalede og med hvilken begrundelse. En enkelt deltager nævnte i den forbindelse at hvis en anbefalet artikel kom fra en kollega ville han læse den - og berører her et emne som social navigation, der er beskrevet yderligere i Davenport (2000). An- befalinger fra intelligente agenter blev derimod mødt med en langt større skepsis, hvor nogle decideret fremhævede at de ville foretrække anbefalinger fra en bibliotekar.

Af andre resultater der lå uden for selve studiets rammer kan nævnes, at flere af deltagerne syntes af have svært ved at overskue hvilke kilder til informationssøgning der i en given situation ville være de mest relevante samt hvordan de skulle foretage en kvalificeret søgning. Det peger på et behov for også at tænke informationskompetence ind i design af personlige informationssystemer, dvs. ikke blot levere information men også vejledning af den enkelte bruger i forhold til dennes behov og 'problemsituation'.

\section{Krav og anbefalinger mhp. systemdesign}

I forbindelse med design af personlige systemer eller systemer med indbyggede personaliseringsmuligheder og-elementer er det vigtigt at have udformet en form for personaliseringsstrategi for både at imødegå nogle af de tidligere nævnte barrierer for hensigtsmæssig implementering samt for at kvalificere brugeroplevelsen i den færdige løsning. Det er således vigtigt på forhånd at have gjort sig klart om det overhovedet er relevant at personalisere, herunder hvilket formål det tjener for udbyder og for bruger. Dernæst er det vigtigt at få afdækket brugerkrav til indhold og funktionalitet på baggrund af en behovsanalyse. Det indebærer endvidere overvejelser mht. valg af personaliseringstilgang samt konkrete overvejelser mht. til valg af analysetilgang og evaluering af designet undervejs og efter implementering. Endelig bør strategien sammenholdes med faktorer som tid og ressourceforbrug.

Til støtte for overvejelserne kan nedenstående punkter bruges som udgangspunkt:

- Hvilke mål skal danne grundlag for personalisering (set fra bruger og udbyder) - er der et personaliseringspotentiale 
- Hvad karakteriserer brugeren, dennes behov, præferencer og adfærd (mhp. at etablere en personlig og tilfredsstillende brugeroplevelse)

- Hvad karakteriserer indholdsressourcerne (mhp. personalisering)

- Hvordan kan vi maksimere brugen og nytten af indholdsressourser - for bruger som for udbyder

- Hvordan kan vi proaktivt guide den enkelte bruger i hans eller hendes informationssøgning mhp. at udvikle dennes informationskompetencer samt tiltro til egen håndtering af information

- Hvordan kan vi minimere brugerens risikooplevelse og optimere tilliden til indholdet af systemet

- Hvordan kan vi understøtte brugerens oplevelse af brugervenlighed, effektivitet og relevans af en personaliseret løsning

- Hvordan kan/skal vi måle eller evaluere brugerens nytte og oplevelse af det personlige informationssystem

\section{Konklusion}

Denne artikel har behandlet det personlige informationssystem ud fra henholdsvis en systemorienteret og en brugerorienteret synsvinkel; først med en gennemgang af tre centrale personaliseringstilgange og deres karakteristika og dernæst med en behandling og diskussion af brugerkrav og deres implikationer for design på baggrund af en case. Opbygning af personlige informationssystemer eller personaliserede informationsmiljøer er en ny og udfordrende opgave for bibliotekarer og informationsspecialister. Selve tankegangen eller filosofien bag personalisering - formidling af relevant indhold - er i og for sig ikke ny, men udviklingsmiljøet og værktøjerne har nødvendiggjort en ny forståelse af hvad det vil sige at formidle information og viden. Det stiller igen krav om udvikling af nye kompetencer - både i konkurrence og i samarbejde med andre faggrupper. I denne nye forståelse af personlig betjening af brugerne som teknologen muliggør, er det imidlertid ikke nok kun at forbinde folk med indhold - personalisering handler nok så væsentligt også om at etablere relationer
- både mellem informationsudbyder og bruger som brugerne imellem.

Personalisering er stadig en ung designfilosofi, der hidtil har været associeret mest med teknologi, applikationer og funktionalitet. Men nu er der behov for forskning og udvikling der i højere grad fokuserer på at forstå hvornår og hvorfor en bruger eller en gruppe af brugere oplever en informationstjeneste, en portal, et digitalt bibliotek, et intranet eller en webside som deres personlige informationssystem.

\section{Noter}

1. Udtrykket er en nutidig omformulering af Ranganathans 'five laws' beskrevet i Ranganathan, $\mathrm{S}$. R. (1957). The five laws of library science. London: Blunt and Sons, Ltd.

2. Persondataloven (2000) sætter selvfølgelig en grænse for hvilke oplysninger man må indhente om brugerne.

\section{Referencer}

Bonett, M. (2001). Personalization of web services and challenges. Lokaliseret den 30. marts 2004 på World Wide Web: http://www.ariadne.ac.uk/ issue28/personalization.

Blom, J.O. \& Monk, A.F. (2003). Theory of personalization of appearance: why users personalize their PCs and mobile phones. Human-Computer Interaction, vol. 18, 193-228.

Chia, C. (2002). The personalization challenge in public libraries: perspectives and prospects. Gütersloh: Bertelsmann Foundation. 129 p. (research report).

Davenport. E. (2000). "Social intelligence in the age of networks." Journal of Information Science, 26 (3), 145-152. 
Hicks, D.; Tochtermann, K. (2001). Personal Digital Libraries and knowledge management. Journal of Universal Computer Science, 7 (7), 550-565.

Hyldegård, J.; Seiden, P. (2004). My e-journal - exploring the usefulness of personalized access to scholarly articles and services. Information Research, Vol. 9, No. 3. Lokaliseret den 27. april 2004 på World Wide Web: http://informationr.net/ir/ 9-3/paper181.html.

Instone, K. (2000). Information Architecture and personalization - an information architecture based framework for personalization systems. (Whitepaper, Argus Associates). Lokaliseret den 30. marts 2004 på World Wide Web: http://argus-acia.com.

Lov om behandling af personoplysninger, L.nr. 429 af 31.5.2000.

Manber, U., Patel, A. \& Robinson, J. (2000) "Experience with personalization on Yahoo." Communications of the ACM, 43(8), 35-39.
Neuhold, E. ; Niederée, C.; \& Stewart, A. (2003). Personalization in digital libraries - an extended view. ICADL 2003, LNCS 2911. Ed. By T.M.T. Sembok et al. 1-16.

Reamy, T. (2001) "From information architecture to knowledge architecture. Intranet Professional, 4(5), 5-6.

Rusch-Feja, D. \& Siebeky, U. (1999) "Evaluation of usage and acceptance of electronic journals." $D$ Lib Magazine, 5(10). Lokaliseret d. 30. marts 2004 på World Wide Web: http://www.dlib.org/dlib/ october99/rusch-feja/10rusch-feja-full-report.html (30 May 2003).

Tenopir, C. \& King, D. W. (2002) "Reading behaviour and electronic journals." Learned Publishing, 15 (4), 259-265.

Tenopir, C., King, D. W., Boyce, P., Grayson, M., Zhang, Y. \& Ebuen, M. (2003) "Patterns of journal use by scientists through three evolutionary phases" D-Lib Magazine, 9 (5). Lokaliseret d. 31. marts 2004 på World Wide Web: http://www.dlib.org/dlib/ may03/king/05king.html. 